\title{
Compressive Strength of New Glass lonomer Cement Technology based Restorative Materials after Thermocycling and Cyclic Loading
}

\section{Kompresijska čvrstoća restaurativnih materijala temeljenih na novoj tehnologiji stakleno-ionomernih cemenata nakon termocikliranja i cikličkog opterećenja}

\footnotetext{
${ }^{1}$ Department of Endodontics and Restorative Dentistry, School of Dental Medicine, University of Zagreb, Gundulićeva 5, 10000 Zagreb, Croatia Zavod za endodonciju i restaurativnu stomatologiju Stomatološkog fakulteta Sveučilišta u Zagrebu, Hrvatska

2 Department of Restorative Dentistry, School of Dentistry, Hacettepe University, Ankara 06100, Turkey Zavod za restaurativnu stomatologiju Stomatološkog fakulteta Sveučilišta Hacettepe, Ankara, Turska
}

\section{Abstract}

Objective: The objective of the study was to compare compressive strengths of two glass ionomerbased materials, with and without a light-cured, nano-filled coating, after cyclic loading and thermocycling. Materials and methods: To determine compressive strength of new restorative materials over a longer period of time, materials were analysed under simulated conditions where cyclic loading replicated masticatory loading and thermocycling simulated thermal oscillations in the oral cavity. Four groups of samples $(n=7)$ - (1) Equia Fil (GC, Tokyo, Japan) uncoated; (2) Equia Fil coated with Equia Coat (GC, Tokyo, Japan); (3) Equia Forte Fil (GC, Tokyo, Japan) uncoated; and (4) Equia Forte Fil coated with Equia Forte coat (GC, Tokyo, Japan) - were subjected to cyclic loading (240,000 cycles) using a chewing simulator (MOD, Esetron Smart Robotechnologies, Ankara, Turkey). Results: Compressive strength measurements were performed according to ISO 9917-1:2007, using the universal mechanical testing machine (Instron, Lloyd, UK). Scanning electron microscope (SEM) analysis was performed after thermocycling. There were no statistically significant differences between Equia Fil and Equia Forte Fil irrespective of the coating $(p<0.05)$, but a trend of increasing compressive strength in the coated samples was observed. Conclusions: Coating increases the compressive strength of Equia Fil and Equia Forte Fil, but not significantly.
Received: September 30, 2019

Accepted: December 1, 2019

Address for correspondence

Ana Ivaniševic Malčić

University of Zagreb

School of Dental Medicine

Department of Endodontics and

Restorative Dental Medicine

Phone +38514802126

Fax +38514802159

aivanisevic@sfzg.hr

Key words

Glass Ionomer Cements; Compressive Strength; Hardness Tests; Mastication

\section{Introduction}

Glass ionomer cements (GICs) are widely used in dentistry due to their biocompatibility, chemical adhesion to dental tissues, and anticariogenic potential (1-3). Their relatively weak mechanical properties, however, have prompted numerous research efforts focused on improving their overall hardiness and clinical performance as long-term fillings in posterior teeth (4-7).

For example, water balance has been shown to play an important role in achieving optimal physical properties in glass ionomer materials. In the initial setting phase, which includes the neutralization reaction between metal cations released from the glass and polymeric acid, glass ionomer materials are sensitive to water and the cement sets within 3-6 minutes $(2,8)$. Dissolution of metal cations during the setting process can be avoided by protecting the cement from additional water. Once the cement has set, the maturation process

\section{Uvod}

Stakleno-ionomerni cementi u širokoj su uporabi u dentalnoj medicini zbog biokompatibilnosti, kemijske veze sa zubnim tkivima i antikariogenog potencijala (1-3). Njihova razmjerno slaba mehanička svojstva ubrzala su istraživačke napore usmjerene prema povećanju njihove svekolike otpornosti i kliničkih svojstava za dugotrajne ispune stražnjih zuba (4-7).

Na primjer, ravnoteža vode pokazala se važnom u postizanju optimalnih fizikalnih svojstava u stakleno-ionomernim materijalima. Početna faza stvrdnjavanja, koja traje od 3 do 6 minuta i uključuje reakciju neutralizacije između metalnih kationa oslobođenih iz stakla i polimerne kiseline, osjetljiva je na vodu $(2,8)$. Otapanje metalnih kationa tijekom stvrdnjavanja može se izbjeći zaštitom cementa od dodatne vode. $\mathrm{Na}$ kon što se cement stvrdne, proces maturacije događa se sljedeća 24 sata te čak do godinu dana (2). Tijekom maturacije 
occurs during the next 24 hours and up to a year afterward (2). During maturation, care must be taken to avoid the cement becoming dehydrated, which leads to surface cracking and a chalky appearance (9).

For this reason, there are several surface protection coatings commonly used in clinical practice that are applied in order to prevent the early loss of ions participating in the setting reaction, and also to prevent water loss later on (10). Mechanical properties of the glass ionomer-in particular, the surface hardness-were shown to improve after a coating was applied (11). The coat is responsible for the glaze effect that enhances the aesthetics of the set material; it also provides effective protection during the water-sensitive initial setting phase and has been shown to increase the glass ionomer's compressive strength after fatigue strength and reduce abrasive wear of the filling $(12,13)$.

Equia Coat is a hydrophilic, low-viscosity nano-filled coating agent that consists of 50\% methyl methacrylate and $0.09 \%$ camphorquinone. It is a component of a restorative system based on GIC technology that also consists of Equia Fil. In 2015, Equia Forte (GC, Tokyo, Japan) was released as a new restorative material based on glass hybrid technology where a glass filler matrix combines fillers of different sizes. It consists of microlaminated Equia Forte Fil with a nano-filled coat (Equia Forte Coat, GC, Tokyo, Japan) (14). Similarly as in the Equia Coat, in the Equia Forte Coat, nanofiller particles are dispersed in the liquid. Additionally, the Equia Forte Coat contains a multifunctional monomer that, as the manufacturer claims, improves surface hardness and wears resistance.

The standard techniques for assessing the strength of dental materials include determining compressive strength (CS) $(15,16)$. To determine compressive strength, the mechanical properties of tested materials are analyzed over a longer period of time and under simulated conditions where cyclic loading replicates masticatory loading and thermocycling simulates thermal oscillations in the oral cavity (17). The purpose of this in vitro study was to assess CS values for the two new restorative materials, with and without coating after cyclic loading and thermocycling, and to determine whether the nano-filled coating influences CS values after the initial setting and before moisture contamination. The hypothesis of the study was that the compressive strength of the tested materials would be higher after cyclic loading and thermocycling if they had been treated initially with a nano-filled coating.

\section{Materials and methods}

This in vitro study was approved by the Ethics Committee of the School of Dental Medicine, University of Zagreb, approval number 05-PA-15-12/2017.

\section{Sample preparation}

The two restorative materials used in this study were Equia Fil GC (Tokyo, Japan) and Equia Forte Fil GC (Tokyo, Japan). The samples were divided into uncoated groups and groups coated with either Equia Coat or Equia Forte Coat (GC, Tokyo, Japan).

Cylindrical aluminum molds $(6 \mathrm{~mm}$ diameter x $3 \mathrm{~mm}$ height) were used to prepare the samples. The materials were valja paziti da se ne dogodi dehidracija cementa jer rezultira površinskim pucanjem i kredastim izgledom (9).

Zbog toga postoji nekoliko površinskih zaštitnih premaza koji se obično upotrebljavaju u kliničkoj praksi za sprječavanje ranog gubitka iona koji sudjeluju u procesu stvrdnjavanja te kasnijeg gubitka vode iz materijala (10). Pokazalo se da su mehanička svojstva staklenih ionomera, posebno površinska tvrdoća, poboljšani nakon aplikacije premaza (11). Premaz je također odgovoran za sjaj koji poboljšava estetiku stvrdnutog materijala i pruža učinkovitu zaštitu tijekom početne faze stvrdnjavanja osjetljive na prisutnost vode, a pokazalo se da povećava i kompresijsku čvrstoću staklenih ionomera nakon cikličkog opterećenja te smanjuje abrazivno trošenje ispuna $(12,13)$.

Equia Coat je hidrofilni niskoviskozni nanopunjeni premaz koji se sastoji od $50 \%$ metil-metakrilata i 0,09 \% kamforkinona. On je komponenta u restaurativnom sustavu temeljenom na GIC tehnologiji koji uključuje i Equia Fil. Godine 2015. pojavio se na tržištu novi restaurativni materijal Equia Forte (GC, Tokio, Japan) proizveden na temelju staklo-hibridne tehnologije u kojem je matrica staklenog punila kombinacija čestica punila različitih veličina. Sastoji se od Equia Forte Fila mikrolaminiranog nanopunjenim premazom (Equia Forte Coat, GC, Tokio, Japan) (14). Slično kao u Equia Coatu, i u Equia Forte Coatu čestice nanopunila raspršene su u tekućini. Uz to, Equia Forte Coat sadržava multifunkcionalni monomer za koji proizvođač tvrdi da poboljšava površinsku tvrdoću i otpornost na trošenje.

Standardni postupak za procjenu čvrstoće dentalnih materijala uključuje određivanje kompresijske čvrstoće (CS-a) $(15,16)$. Kako bi se odredilo mehaničko svojstvo kompresijske čvrstoće ispitivanih materijala tijekom duljeg razdoblja, simulirani su uvjeti mastikatornog opterećenja cikličkim opterećenjem i termičke oscilacije u usnoj šupljini termocikliranjem (17). Svrha ovog istraživanja in vitro bila je procijeniti vrijednosti CS-a dvaju novih restaurativnih materijala, s premazom ili bez njega, nakon cikličkog opterećenja i termocikliranja, te odrediti utječe li nanopunjeni premaz, apliciran nakon inicijalnog stvrdnjavanja prije kontaminacije vlagom, na kompresijsku čvrstoću. Hipoteza ovog istraživanja bila je da će vrijednosti CS-a ispitivanih materijala nakon cikličkog opterećenja i termocikliranja biti veće ako su inicijalno bili premazani zaštitnim nanopunjenim premazom.

\section{Materijali i metode}

Ovu studiju in vitro odobrilo je Etičko povjerenstvo Stomatološkog fakulteta Sveučilišta u Zagrebu (broj odobrenja 05-PA-15-12/2017).

\section{Priprema uzoraka}

U ovom istraživanju korišstena su dva restaurativna materijala - Equia Fil GC (Tokio, Japan) i Equia Forte Fil GC (Tokio, Japan). Uzorci su podijeljeni u nepremazane skupine i skupine premazane Equia Coatom ili Equia Forte Coatom (GC, Tokio, Japan).

Cilindrični aluminijski kalupi (6 mm u promjeru x $3 \mathrm{~mm}$ u visinu) korišteni su za pripremu uzoraka. Materijali su pri- 
prepared according to the manufacturer's instructions and packed into the molds at room temperature. The top surface of each specimen was covered with a celluloid strip and a glass slide, and the specimen was allowed to set in a moist environment in an incubator for $10 \mathrm{~min}$. The specimens were then removed from the molds by applying pressure at one side of the samples. Equia Coat was applied on every second Equia Fil sample, and Equia Forte Coat was applied on every second Equia Forte Fil sample; both types of the coated samples were light-cured from each side for $20 \mathrm{~s}$ using a Bluephase C 8 Light Unit (Vivadent, Schaan, Liechtenstein). There were four experimental groups, each containing seven samples: (1) Equia Fil coated, (2) Equia Fil uncoated, (3) Equia Forte Fil coated, and (4) Equia Forte Fil uncoated. After coating, the samples were stored in a moist environment at $37^{\circ} \mathrm{C}$ for $24 \mathrm{~h}$. The compositions of the samples used in the study are shown in Table 1. premljeni prema uputama proizvođača i stavljeni u kalupe na sobnoj temperaturi. Površina svakog uzorka prekrivena je celuloidnom ljepljivom vrpcom i stakalcem te su uzorci ostavljeni 10 minuta da se stvrdnu u vlažnom okolišu u inkubatoru. Nakon toga su uklonjeni iz kalupa primjenom pritiska $s$ jedne strane kalupa. Equia Coat apliciran je na svaki drugi uzorak Equia Fila, a Equia Forte Coat na svaki drugi uzorak Equia Forte Fila; obje skupine premazanih uzoraka osvijetljene su s obiju strana svjetiljkom Bluephase $\mathrm{C} 8^{\circ}$ (Vivadent, Schaan, Lihtenštajn). Svaka od četiriju eksperimentalnih skupina sadržavala je sedam uzoraka: (1) Equia Fil s premazom, (2) Equia Fil bez premaza, (3) Equia Forte Fil s premazom i (4) Equia Forte Fil bez premaza. Nakon aplikacije premaza uzorci su 24 sata bili pohranjeni u vlažnom ambijentu na temperaturi od $37^{\circ} \mathrm{C}$. Sastavi materijala korištenih u istraživanju navedeni su u tablici 1 .

\begin{tabular}{|c|c|c|}
\hline Glassionomer cement & Powder & Liquid \\
\hline Equia Fil & Fluoro-alumino-silicate glass & Polyacrylic acid, polybasic carboxylic acid \\
\hline Equia Forte Fil & $\begin{array}{l}95 \% \text { strontium fluoroaluminosilicate glass (including } \\
\text { highly reactive small particles) }+5 \% \text { polyacrylic acid }\end{array}$ & $40 \%$ aqueous polyacrylic acid \\
\hline Equia Coat & \multicolumn{2}{|c|}{ Methyl methacrylate, colloidal silica, camphorquinone, urethane methacrylate, phosphoric ester monomer } \\
\hline Equia Forte Coat & \multicolumn{2}{|c|}{$\begin{array}{l}\text { methyl methacrylate (MMA) photoinitiator, synergist, phosphoric acid ester monomer, butylated hydroxytoluene } \\
\text { (BHT) }\end{array}$} \\
\hline
\end{tabular}

\section{Compressive strength measurements and SEM evaluation of the samples}

The specimens were subjected to thermocycling $(10,000$ cycles of $5^{\circ} \mathrm{C}$ and $55^{\circ} \mathrm{C}, 100 \mathrm{~s}$ per cycle, and a $5 \mathrm{~s}$ interval to remove water from the chambers). After thermocycling, wear simulation was performed using a chewing simulator (MOD, Esetron Smart Robotechnologies, Ankara, Turkey). A mass of $5 \mathrm{~kg}$, comparable to $49 \mathrm{~N}$ of chewing force, was exerted (18). According to the previous studies, 240,000-250,000 loading cycles in a chewing simulator are equivalent to approximately one year of chewing $(19,20)$. The wear test included 240,000 loading cycles to clinically simulate the one-year chewing condition. After cycle loading, the specimens were stored in distilled water at room temperature for one week prior to compressive strength measurements.

The compressive strength measurements for the tested materials were performed at room temperature $\left(23 \pm 1^{\circ} \mathrm{C}\right)$ according to ISO 9917-1:2007. The compressive strength was determined by loading at a crosshead speed of $1 \mathrm{~mm} / \mathrm{min}$ until specimen failure. A universal mechanical testing machine was used (Instron, Lloyd, UK). The fracture load was recorded for each sample, and compressive strength was calculated using the equation $C S=4 \mathrm{~F} /\left(\pi \mathrm{D}^{2}\right)$, wherein $\mathrm{CS}$ stands for compressive strength, $\mathrm{F}$ is the maximum applied load in Newtons $(\mathrm{N})$, and $\mathrm{D}$ is the diameter of the specimen in mm (app. $4 \mathrm{~mm}$ ).

\section{Mjerenje kompresijske čvrstoće i SEM evaluacija uzoraka}

Uzorci su podvrgnuti termocikliranju (10 000 ciklusa na 5 ${ }^{\circ} \mathrm{C}$ i $55^{\circ} \mathrm{C}$, 100 sekunda po ciklusu, interval od 5 sekunda, interval za uklanjanje vode iz komora). Poslije termocikliranja, mastikatorno trošenje simulirano je s pomoću simulatora žvakanja (MOD, Esetron Smart Robotechnologies, Ankara, Turska). Primijenjena je masa od 5 kilograma, ekvivalentna žvačnoj sili od $49 \mathrm{~N}$ (18). Prema dosadašnjim istraživanjima, od 240000 do 250000 opterećujućih ciklusa u žvačnom simulatoru ekvivalentno je otprilike jednoj godini žvakanja $(19,20)$. Test trošenja sastojao se od 240000 cikličkih opterećenja kako bi se simuliralo kliničko stanje nakon jedne godine žvakanja. Nakon cikličkog opterećenja uzorci su bili jedan tjedan pohranjeni u destiliranoj vodi na sobnoj temperaturi.

Mjerenja kompresijske čvrstoće provedena su na sobnoj temperaturi $\left(23 \pm 1{ }^{\circ} \mathrm{C}\right)$ prema ISO 9917-1:2007. Kompresijska čvrstoća određena je opterećenjem pri brzini klipa od 1 $\mathrm{mm} / \mathrm{min}$. do pucanja uzorka. Korišten je univerzalni uređaj za mjerenja mehaničkih svojstava (Instron, Lloyd, UK). Opterećenje pri pucanju zabilježeno je za svaki uzorak, a kompresijska čvrstoća izračunata je prema formuli $\mathrm{CS}=4 \mathrm{~F} /(\pi$ $\mathrm{D}^{2}$ ), u kojoj je CS kompresijska črrstoća, F maksimalna aplicirana sila u njutnima $(\mathrm{N})$, a D promjer uzorka u milimetrima (otprilike $4 \mathrm{~mm}$ ). 


\section{SEM evaluation of the samples}

The specimens were analysed using SEM after thermocycling. They were placed into an electrically conductive polymer mass; grinded at $300 \mathrm{rpm}$ using water cooling and sandpaper (P320, P500, P1000, P2400, P4000); and polished at $150 \mathrm{rpm}$ with $30 \mathrm{~N}$ force applied using diamond pastes (3 $\mu \mathrm{m}$ and $1 \mu \mathrm{m})$ and lubricant. Subsequently, they were gold sputter-coated and observed under SEM (JSM-6400 SEM, JEOL, Tokyo, Japan) at 20, 200, and 1,000 times magnification.

\section{Statistical analysis}

Statistical analysis was performed using the SAS statistical package. The Shapiro-Wilk test was used to analyze the normality of distribution. The Kruskal-Wallis test and factorial ANOVA were used to compare the differences between the sample groups at the level of significance $\mathrm{p}=0.05$.

\section{Results}

The distribution of compressive strength measurements for all groups of samples was normal (the Shapiro-Wilk test). The Kruskal-Wallis test and factorial ANOVA analysis showed that there were no statistically significant differences between Equia Fil and Equia Forte Fil irrespective of the coating (Table 2), but a trend of increasing compressive strength in the coated samples was observed (Figure 1).

The SEM evaluation showed that when the samples were not coated prior to thermocycling, Equia Fil and Equia Forte Fil specimens were abraded with surface microcracks present (Figure 2).

\section{Discussion}

The results of this study showed that the compressive strength of Equia Fil and Equia Forte Fil after cyclic loading and thermocycling was higher when the samples were coated after initial setting with Equia Coat and Equia Forte Coat, respectively, but the differences were not statistically significant. These results are in agreement with some previous studies that also reported that applying a low-viscosity coating agent after initial setting enhanced the mechanical properties of the material (11). A recent report claims that there has been improvement in mechanical properties of the fastsetting GICs with simplified application procedures, i.e., in the absence of a protective varnish (21). However, this find-

\section{SEM evaluacija uzoraka}

Uzorci su analizirani SEM-om nakon termocikliranja. Postavljeni su u eklektrično vodljivu polimernu masu, izbrušeni brusnim papirom (P320, P500, P1000, P2400, P4000) uz vodeno hlađenje na $300 \mathrm{rpm}$ i polirani uz silu od $30 \mathrm{~N}$ i $150 \mathrm{rpm}$ dijamantnim pastama (3 $\mu \mathrm{m}$ i $1 \mu \mathrm{m})$ i lubrikantom. Uzorci su zatim prekriveni zlatnim prahom i analizirani pod SEM-om (JSM-6400 SEM, JEOL, Tokio, Japan) na povećanju od 20, 200 i 1000 puta.

\section{Statistička analiza}

Statistička analiza provedena je statističkim paketom SAS. Normalnost distribucije analizirana je Shapiro-Wilkovim testom. Razlike među skupinama na razini značajnosti $p$ $=0,05$ određene su Kruskal-Wallisovim testom i faktorijalnom analizom ANOVA.

\section{Rezultati}

Distribucija vrijednosti kompresijske čvrstoće za sve skupine uzoraka bila je normalna (Shapiro-Wilkov test). Kruskal-Wallislov test i faktorijalna analiza ANOVA pokazali su da nema statistički značajne razlike između Equia Fila i Equia Forte Fila, neovisno o premazu (tablica 2.), ali zabilježen je trend povećanja kompresijske čvrstoće u premazanim uzorcima (slika 1.).

SEM evaluacija pokazala je na uzorcima Equia Fila i Equia Forte Fila, koji nisu bili premazani nakon inicijalnog stvrdnjavanja, abradiranu površinu s mikropukotinama (slika 2.).

\section{Rasprava}

Rezultati ovog istraživanja pokazali su da je kompresijska čvrstoća Equia Fila i Equia Forte Fila, nakon termocikliranja i cikličkog opterećenja, bila veća kada su uzorci nakon inicijalnog stvrdnjavanja bili premazani Equia Coatom, odnosno Equia Forte Coatom, no razlike nisu bile značajne. Ti se rezultati podudaraju s rezultatima nekih prijašnjih istraživanja u kojima je također istaknuto da je aplikacija nisko-viskoznog premazujućeg sredstva nakon inicijalnog stvrdnjavanja poboljšala mehanička svojstva materijala (11). Novije je, pak, istraživanje pokazalo poboljšanje mehaničkih svojstava brzostvrdnjavajućeg GIC-a s pojednostavnjenim postupkom primjene, tj. bez zaštitnog premaza/varnisha (21). Ipak, ovaj re-

Table 2 There were no statistically significant differences between coated and uncoated Equia Fil and Equia Forte Fil groups. Tablica 2. Između premazanih i nepremazanih uzoraka Equia Fila i Equia Forte Fila nije bilo statistički značajne razlike

\begin{tabular}{l|c|c|c|c} 
& \multicolumn{2}{c|}{$\begin{array}{c}\text { Stress at maximum } \\
\text { load (MPa) }\end{array}$} & $\begin{array}{c}\text { Factorial } \\
\text { ANOVA }\end{array}$ & $\begin{array}{c}\text { Kruskal- } \\
\text { Wallis }\end{array}$ \\
\hline & Mean & St.dev. & p & p \\
\hline EQUIA Forte Coating (+) & 198.02 & $(37.68)$ & 0,126 & \\
\hline EQUIA Forte Coating (-) & 175.57 & $(36.22)$ & & \\
\hline EQUIA Coating (+) & 172.80 & $(25.37)$ & & \\
\hline EQUIA Coating (-) & 163.81 & $(19.67)$ & & \\
\hline Factor & & & & 0.1185 \\
\hline Material & & & 0.1815 & 0.1078 \\
\hline Coating & & & & 0.3346 \\
\hline
\end{tabular}




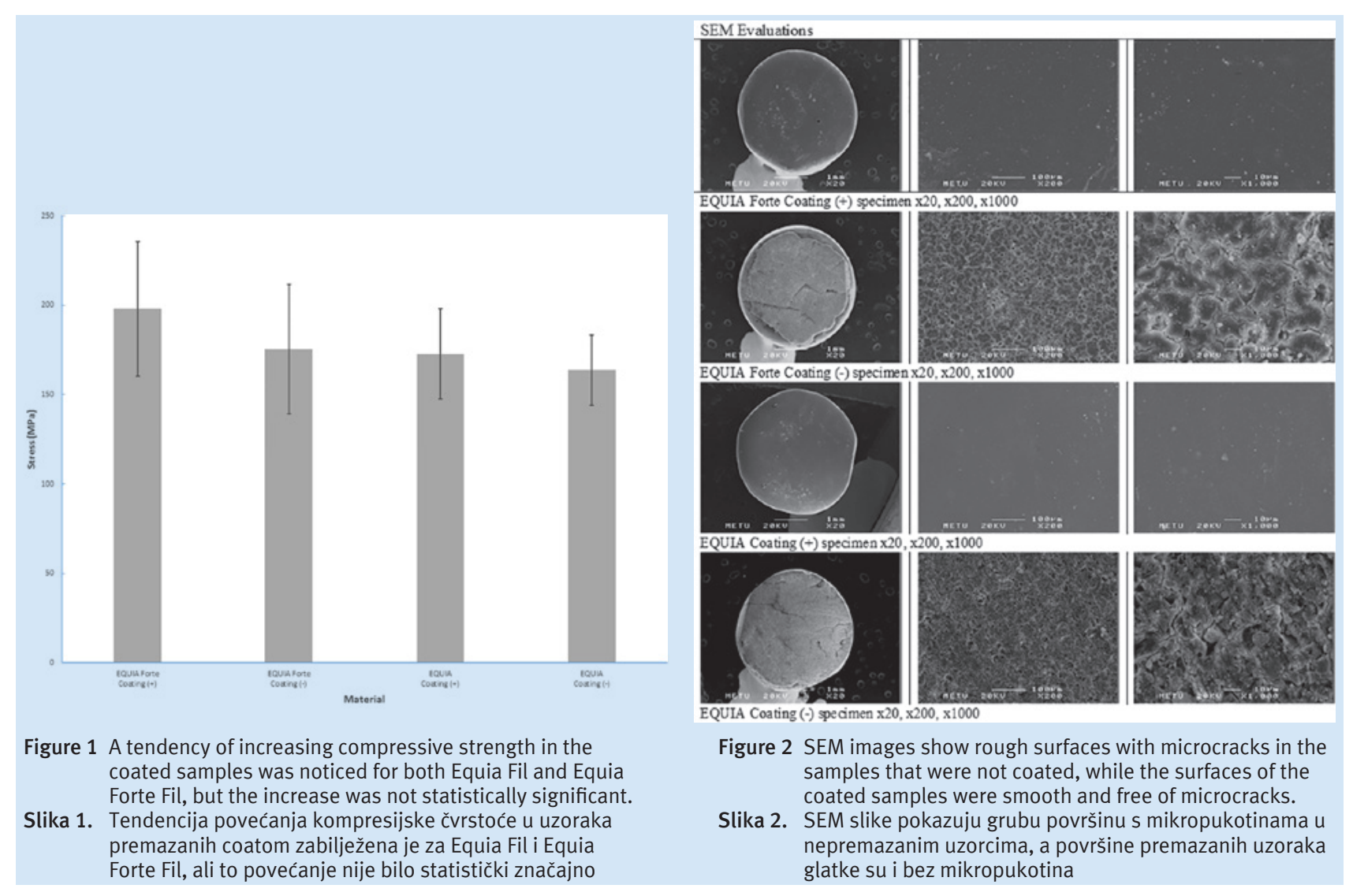

ing cannot be interpreted as inconsistent with the results of this research since nano-filled coating agents were used instead of varnish.

Furthermore, in this study, Equia Forte Fil exhibited higher compressive strength than Equia Fil. This can be explained by the fact that the glass-hybrid concept of the Equia Forte restorative system, where the filler particles of approximately $25 \mu \mathrm{m}$ are combined with highly reactive smaller particles $(4 \mu \mathrm{m})$, contributes to the increase in the material's strength (22). Furthermore, the nano-multifunctional monomer within the Equia Forte Coat improves the physical properties of the overall restorative system. This monomer used in Equia Forte Coat is functionalized with more functional groups to promote crosslinking, flexibility or adhesion.

Although we did not evaluate clinical performance, we can assume that the improved physical properties should contribute to enhanced clinical performance (14). We can therefore correlate our findings with the results of some clinical studies that reported that the coating did not significantly improve clinical performance of the GIC materials in terms of reduced occlusal wear and increased survival rates $(23,24)$.

The observed increase of CS in the coated samples, although not statistically significant, could be explained by the reduction of undesirable early water exchange (25). The application of a coating on the newly placed GIC was, therefore, recommended to prevent the water escape before it became strongly bound by hydration of the cations released from the glass or siloxane groups on the surface of glass particles $(26,27)$. In the present study the specimens were stored in distilled water before the compressive strength measure- zultat ne može se smatrati proturječnim rezultatima u ovom istraživanju jer je u ovom istraživanju upotrijebljen nanopunjeni svjetlosno-polimerizirajući premaz (coat), a ne jednostavni premaz (varnish).

Nadalje, ovo je istraživanje pokazalo da je kompresijska čvrstoća Equia Forte Fila veća od one Equia Fila. To se može objasniti staklohibridnim konceptom restaurativnog sustava Equia Forte, u kojem su čestice punila veličine otprilike $25 \mu \mathrm{m}$ kombinirane $s$ visokoreaktivnim manjim česticama (4 $\mu \mathrm{m})$, što pridonosi povećanju čvrstoće materijala (22). Osim toga, nanomultifunkcionalni monomer u Equia Forte Coatu poboljšava fizikalna svojstva cijeloga restaurativnog sustava. Monomer u Equia Forte Coatu funkcionaliziran je s više funkcionalnih skupina koje promiču križno povezivanje, fleksibilnost i adheziju.

Premda u ovom radu nije istraživano kliničko ponašanje, može se pretpostaviti da poboljšana fizikalna svojstva pridonose kliničkom poboljšanju (14). Zato se naši rezultati mogu usporediti s rezultatima nekih kliničkih studija u kojima je istaknuto da premazivanje coatom nije značajno poboljšalo kliničku izvedbu GIC-a kad je riječ o smanjenom okluzalnom trošenju i produženom trajanju ispuna $(23,24)$.

Uočeno povećanje CS-a u premazanim uzorcima, premda nije bilo statistički značajno, može se objasniti smanjenjem nepoželjne rane izmjene vode (25). Primjena coata na novopostavljeni GIC stoga se preporučuje kako bi se spriječila dehidracija prije čvrstog vezanja vode hidracijom kationa otpuštenih iz stakla ili siloksanskih skupina na površini staklenih čestica $(26,27)$. U ovom su istraživanju uzorci prije mjerenja kompresijske čvrstoće bili pohranjeni u destilira- 
ments were taken, but it was not expected that the storage in water would influence the water sorption in the uncoated groups since the escape of loosely bound water was shown to be critical at this stage, as mentioned earlier (27).

After the acid-base reaction, clinically described as the initial setting, the maturation process takes place within the material until complete setting occurs (28). The water absorbed in the maturation phase occupies coordination sites around metal cations or hydration regions around the polyanion chain within the set cement (9). This enables shrinkage compensation, and the proportion of loosely bound water decreases relative to the proportion of tightly bound water as the cement matures $(9,29)$. The maturation results in altered mechanical properties for GICs, and compressive strength increases asymptotically to a stable value higher than the one found at 24 hours $(28,30)$.

The increase in compressive strength during the initial period of a few weeks after placement was established for conventional glass ionomers decades ago, and it seems to occur faster in modern, highly viscous glass ionomers, where the increase in CS is significant during the first day and rises further until one week after placement $(31,32,28)$. In this study, the compressive strength of the tested GIC materials was not determined after the initial setting or after $24 \mathrm{~h}$, hence we cannot draw any conclusions about how the CS values changed over time within one group of samples. However, when comparing compressive strength values exhibited by the materials used in this study with the compressive strength values of other fast-setting glass ionomers, we can observe that the values obtained after aging simulations are similar to those obtained after 24 hours in a previous study (33). This might imply that thermocycling does not reduce compressive strength in GIC materials, as already reported (34).

Our results further suggest that coating Equia Fil and Equia Forte Fil rendered their surface free of microcracks, possibly due to more favorable water balances during the first 24 hours that enabled complete maturation. The SEM pictures taken after thermocycling show smooth and microcrack-free surfaces of glass ionomer samples coated with Equia Coat (Figure 2). This also shows that the nano-filled coat does not readily wear off. In this research, we did not focus on occlusal wear or volumetric loss of the loaded material based on GIC technology, but we can assert that the coat visualized on SEM images after thermocycling is consistent with the previously reported reduced occlusal wear of a GICbased material protected by a surface resinous coating (12).

\section{Conclusion}

The clinically important mechanical property of compressive strength after thermocycling and cyclic loading was not found to be significantly improved by coating glass ionomer based restorative materials with nano-filled resinous coats, although a trend toward increase was recorded in the coated samples. noj vodi, no nije se očekivalo da će to utjecati na upijanje vode nepremazanih uzoraka jer se pokazalo da je gubitak slabo vezane vode u ovoj fazi kritičan, kako je već spomenuto (27).

Nakon acido-bazne reakcije, klinički opisane kao inicijalno stvrdnjavanje, slijedi proces maturacije unutar materijala do potpunog stvrdnjavanja (28). Voda apsorbirana u procesu maturacije zauzima koordinacijska mjesta oko metalnih kationa ili područja hidracije oko polianionskog lanca unutar stvrdnutog cementa (9). To kompenzira kvrčenje, a kako cement maturira, smanjuje se udio slabo vezane vode u odnosu prema udjelu snažno vezane vode $(9,29)$. Maturacija rezultira promijenjenim mehaničkim svojstvima GIC-a, a kompresijska čvrstoća asimptotski se povećava do stabilne vrijednosti, veće od one nakon 24 sata $(28,30)$.

Povećanje kompresijske čvrstoće u prvih nekoliko tjedana nakon postavljanja utvrđena je za konvencionalne staklene ionomere prije više desetljeća, a čini se da se događa brže u modernim, visoko viskoznim staklenim ionomerima, u kojima je povećanje CS-a tijekom prvog dana značajno te se dalje povećava do tjedan dana nakon postavljanja ispuna $(28$, 31,32 ). U ovom istraživanju CS testiranih materijala nije bio određen nakon inicijalnog stvrdnjavanja ili nakon 24 sata, tako da ne možemo zaključiti o promjeni njegove vrijednosti tijekom vremena unutar pojedine skupine. Ipak, kada uspoređujemo CS vrijednosti materijala korištenih u ovom istraživanju s CS vrijednostima ostalih brzovežućih staklenih ionomera, možemo uočiti da su CS vrijednosti nakon simulacije starenja slične onima dobivenima nakon 24 sata (33). To može implicirati da termocikliranje ne smanjuje CS u GIC materijalima, kako je već istaknuto (34).

Naši rezultati nadalje sugeriraju da je premazivanje Equia Fila i Equia Forte Fila rezultiralo površinom bez mikropukotina, možda zbog povoljnije ravnoteže vode u prva 24 sata, što je omogućilo potpunu maturaciju. SEM slike napravljene nakon termocikliranja pokazuju glatke površine bez mikrofraktura uzoraka staklenih ionomera premazanih coatom (slika 2.). To također pokazuje da se nanopunjeni premaz ne troši odmah. U ovom istraživanju nismo se usredotočili na okluzalno trošenje i volumetrijski gubitak opterećivanih materijala temeljenih na GIC tehnologiji, ali možemo tvrditi da je vizualizirani premaz na SEM slikama nakon termocikliranja u skladu s objavljenim rezultatima smanjenoga okluzalnog trošenja materijala temeljenih na GIC-u zaštitnim površinskim smolastim premazom (12).

\section{Zaključak}

Klinički važno mehaničko svojstvo kompresijske čvrstoće nakon termocikliranja i cikličkog opterećenja nije značajno poboljšano nakon premazivanja nanopunjenim smolastim premazima restaurativnih materijala temeljenih na staklenim ionomerima, iako je uočen trend prema povećanju CS-a u premazanim uzorcima. 


\section{Acknowledgments}

This study was founded by the Croatian Science Foundation, which is dedicated to the "investigation and development of new micro and nanostructure bioactive materials in dental medicine" (BIODENTMED No. IP-2018-01-1719).

The results of this research were presented at CED IADR meeting in Madrid 18-22 September 2019.

\section{Conflict of interest}

None declared.

\section{Zahvala}

Studija je odobrena u Hrvatskoj zakladi za znanost i posvećena je istraživanju i razvoju novih mikro i nanostrukturnih bioaktivnih materijala u dentalnoj medicini (BIODENTMED br. IP-2018-01-1719).

Rezultati ovog istraživanja predstavljeni su na sastanku CED IADR-a u Madridu od 18. do 22. rujna 2019. godine.

\section{Sukob interesa}

Autori nisu bili u sukobu interesa.

\section{Sažetak}

Svrha rada: Željela se usporediti, nakon cikličkog opterećenja i termocikliranja, kompresijska (tlačna) čvrstoća dvaju materijala temeljenih na staklenim ionomerima sa svjetlosno polimerizirajućim nanopunjenim premazom ili bez njega. Materijali i metode: Kako bi se odredila kompresijska čvrstoća novih restaurativnih materijala tijekom duljeg razdoblja, analizirani su nakon simulacije mastikatornog opterećenja cikličkim opterećenjem i termalnih oscilacija u usnoj šupljini termocikliranjem. Četiri skupine uzoraka $(n=7)$ - (1) Equia Fil (GC, Tokio, Japan) bez premaza, (2) Equia Fil premazan Equia Coatom (GC, Tokio, Japan), (3) Equia Forte Fil (GC, Tokio, Japan) bez premaza i (4) Equia Forte Fil premazan Equia Forte coatom (GC, Tokio, Japan) - podvrgnuti su cikličkom opterećenju (240 000 ciklusa) u žvačnom simulatoru (MOD, Esetron Smart Robotechnologies, Ankara, Turska). Rezultati: Mjerenja kompresijske čvrstoće provedena su prema standardima ISO 9917-1:2007. na univerzalnom uređaju za mjerenja mehaničkih svojstava (Instron, Lloyd, UK). Analiza Scanning elektronskim mikroskopom (SEM) obavljena je nakon termocikliranja. Nije bilo statistički značajne razlike između materijala Equia Fil i Equia Forte Fil, neovisno o premazu $(p<0,05)$, ali je zabilježen trend povećanja kompresijske čvrstoće na premazanim uzorcima. Zaključak: Premaz povećava kompresijsku čvrstoću Equia Fila i Equia Forte Fila, ali ne značajno.
Zaprimljen: 30. rujna 2019.

Prihvaćen: 1. prosinca 2019.

Adresa za dopisivanje

Ana Ivanišević Malčić

Sveučilište u Zagrebu

Stomatološki fakultet

Zavod za endodonciju i restaurativnu dentalnu medicinu

tel: +38514802126

faks: +38514802159

aivanisevic@sfzg.hr

Ključne riječi

stakleno-ionomerni cementi; tlačna čvrstoća; testovi tvrdoće; žvakanje

\section{References}

1. Yip HK, Tay FR, Ngo H, Smales RJ, Pashley DH. Bonding of contemporary glass ionomer cements to dentin. Dent Mater. 2001 Sep;17(5):456-70.

2. Lohbauer U. Dental Glass Ionomer Cements as Permanent Filling Materials? Properties, Limitations and Future Trends. Materials (Basel). 2010;3(1):76-96.

3. Brzović Rajić V, Miletić I, Gurgan S, Peroš K, Verzak Ž, Ivanišević Malčić A. Fluoride Release from Glass Ionomer with Nano Filled Coat and Varnish. Acta Stomatol Croat. 2019 Jun;53(2):132-140.

4. Xie D, Brantley WA, Culbertson BM, Wang G. Mechanical properties and microstructures of glass-ionomer cements. Dent Mater. 2000 Mar;16(2):129-38.

5. Gu YW, Yap AU, Cheang P, Khor KA. Effects of incorporation of $\mathrm{HA} / \mathrm{ZrO}(2)$ into glass ionomer cement (GIC). Biomaterials. 2005 Mar;26(7):713-20.

6. Tjandrawinata R, Irie M, Yoshida Y, Suzuki K. Effect of adding spherical silica filler on physico-mechanical properties of resin modified glassionomer cement. Dent Mater J. 2004 Jun;23(2):146-54.

7. Spajic J, Par M, Milat O, Demoli N, Bjelovucic R, Prskalo K. Effects of Curing Modes on the Microhardness of Resin-Modified Glass Ionomer Cements. Acta Stomatol Croat. 2019 Mar;53(1):37-46.

8. Nicholson JW. Chemistry of glass-ionomer cements: a review. Biomaterials. 1998 Mar;19(6):485-94.

9. Nicholson JW, Wilson AD. The effect of storage in aqueous solutions on glass-ionomer and zinc polycarboxylate dental cements. J Mater Sci Mater Med. 2000;11(6):357-60.

10. Brito CR, Velasco LG, Bonini GA, Imparato JC, Raggio DP. Glass ionomer cement hardness after different materials for surface protection. J Biomed Mater Res A. 2010 Apr;93(1):243-6.

11. Faraji F, Heshmat H, Banava S. Effect of protective coating on microhardness of a new glass ionomer cement: Nanofilled coating versus unfilled resin. J Conserv Dent. 2017 Jul-Aug;20(4):260-263.

12. Diem VTK, Tyas MJ, Hien CN, Phuong LH, Khanh ND. The effect of a nano-filled resin coating on the 3-year clinical performance of a conventional high-viscosity glass-ionomer cement. Clin Oral Investig. $2014 \mathrm{Apr} ; 18(3): 753-9$.

13. Kanik Ö, Turkun LS, Dasch W. In vitro abrasion of resin-coated highly viscous glass ionomer cements: a confocal laser scanning microscopy study. Clin Oral Investig. 2017 Apr;21(3):821-829.
14. Kielbassa AM, Glockner G, Wolgin M, Glockner K. Systematic review on highly viscous glass ionomer cement/resin coating restorations (Part II): Do they merge Minamata Convention and minimum intervention dentistry? Quintessence Int. 2017;48(1):9-18.

15. International Organization for Standardization (ISO). Standard for water-based dental cements. 2007;9911-9917.

16. Šalinović I, Stunja M, Schauperl Z, Verzak Ž, Ivanišević Malčić A, Brzović Rajić V. Mechanical Properties of High Viscosity Glass Ionomer and Glass Hybrid Restorative Materials. Acta Stomatol Croat. 2019 Jun;53(2):125-131.

17. Braem M, Lambrechts $P$, Vanherle G. Clinical relevance of laboratory fatigue studies. J Dent. 1994;22(2):97-102.

18. Krejci I, Mueller E, Lutz F. Effects of thermocycling and occlusal force on adhesive composite crowns. J Dent Res. 1994 Jun;73(6):1228-32.

19. DeLong R, Sakaguchi RL, Douglas WH, Pintado MR. The wear of dental amalgam in an artificial mouth: a clinical correlation. Dent Mater. 1985 Dec;1(6):238-42.

20. Jung YS, Lee JW, Choi YJ, Ahn JS, Shin SW, Huh JB. A study on the invitro wear of the natural tooth structure by opposing zirconia or dental porcelain. J Adv Prosthodont. 2010 Sep;2(3):111-5.

21. Ilie N. Maturation of restorative glass ionomers with simplified application procedure. J Dent. 2018 Dec;79:46-52.

22. Miletic I. Modern solutions for direct posterior restorations. GC Get Connected. 2015;4:32-36.

23. Basso M, Brambilla E, Benites MG, Giovannardi M, Ionescu AC. Glassionomer cement for permanent dental restorations: a 48-months, multi-centre, prospective clinical trial. Stoma Edu J. 2015;2(1):25-35.

24. Hesse D, Bonifácio CC, Bönecker M, Guglielmi Cde A, da Franca $C$, van Amerongen WE et al. Survival rate of atraumatic restorative treatment (art) restorations using a glass ionomer bilayer technique with a nanofilled coating: a bi-center randomized clinical trial. Pediatr Dent. 2016 Jan-Feb;38(1):18-24.

25. Hume WR, Mount GJ. Effect of varnishes and other surface treatments on water movement across the glass-ionomer cement surface. Aust Dent J. 1985 Aug;30(4):298-301.

26. Czarnecka B, Klos J, Nicholson JW. The effect of ionic solutions on the uptake and water-binding behaviour of glass-ionomer dental cements. Ceram Silikáty. 2015;59(4):102-8. 
27. Berg MC, Jacobsen J, Momsen NCR, Benetti AR, Telling MTF, Seydel T, et al. Water dynamics in glass ionomer dental cements. The Eur Phys J Spec Topics. 2016;225(4):773-7.

28. Nicholson JW. Maturation processes in glass-ionomer dental cements. Acta Biomater Odontol Scand. 2018 Jul 31;4(1):63-71.

29. Hankins AD, Hatch RH, Benson JH, Blen BJ, Tantbirojn D, Versluis $A$. The effect of a nanofilled resin-based coating on water absorption by teeth restored with glass ionomer. J Am Dent Assoc. 2014 Apr;145(4):363-70.

30. Mount, GJ. An atlas of glass-ionomer cements: a clinician's guide. 2nd ed. London: Martin Dunitz; 2002.

31. Bresciani E, Barata Tde J, Fagundes TC, Adachi A, Terrin MM, Navarro MF. Compressive and diametral tensile strength of glass ionomer cements. J Appl Oral Sci 2004;12(4):344-8.
32. Crisp S, Lewis BG, Wilson AD. Characterisation of glass-ionomer cements. 1. Long-term hardness and compressive strength. J Dent. 1976 Jul;4(4):162-6.

33. Bonifácio CC, Kleverlaan CJ, Raggio DP, Werner A, Carvalho RC, van Amerongen WE. Physical-mechanical properties of glass ionomer cements indicated for atraumatic restorative treatment. Aust Dent J. 2009 Sep;54(3):233-7.

34. Lohbauer U, Frankenberger R, Krämer N, Petschelt A. Time-dependent strength and fatigue resistance of dental direct restorative materials. J Mater Sci Mater Med. 2003 Dec;14(12):104753. 